\title{
Improving Onion Productivity Grown in Siwa Oasis as Affected by Foliar Spray by K-Silicate and Fertigation by Humic and Amino Acids
}

\author{
Hafez M.R. ${ }^{1}$, El-Desouky G.A. ${ }^{2}$ and EL- Azizy F.A. ${ }^{3}$
}

\begin{abstract}
A field experiment was carried out at Siwa Research Station, Desert Research Center, Khimisa Farm, Matrouh Governorate, during two successive winter seasons, i.e., $2014 / 2015$ and $2015 / 2016$ to study the effect of the fertigation with four combinations of both humic $(\mathrm{H})$ and Amino acids (A) as (control, $2 \mathrm{~L} \mathrm{H}, 2 \mathrm{~L}$ A and $2 \mathrm{~L} \mathrm{H}+2 \mathrm{~L}$ A /fed) as well as the foliar application of three rates of potassium silicate (KS), i.e. , (O, 5 and $10 \mathrm{~g}) \mathrm{KS} / \mathrm{L}$ on the growth, yield parameters, quality content, uptake of $\mathrm{N}$ and $K$ of bulb onion plants and soil available $N$ and $K$ after harvesting. The design of the experiment was split plot technique, where the main factor was the foliar spray of $\mathrm{KS}$, while the sub main were fertigation with $H, A$ and combination. Foliar and soil fertigation treatments were applied at three times, i.e., after 30,60 and 90 days from planting.

Results indicated that the spray rate of $10 \mathrm{~g}$ KS foliar spray/l with (H) and (A) either individually or combination was very effective in improving growth, yield, yield component and quality parameters than applied the spray with of $5 \mathrm{~g} \mathrm{KS} / \mathrm{L}$ during the studied two seasons compared to control treatment. Both rates of $\mathrm{KS}(5$ and $10 \mathrm{~g} / \mathrm{l})$ gave higher increases with (H) application than with (A) application for all the studied parameters. In addition, the best treatment was observed with the integration treatment of $(\mathrm{H}+\mathrm{A}+10 \mathrm{~g} \mathrm{KS} / \mathrm{l})$ which gave the highest mean values of growth, yield, yield component and quality parameters (TSS \%, Protein \% and carbohydrates \%) during the studied two seasons. Where highest mean values reached to, 2.21, 2.10 ton /fed for dry weight of bulb; 15.33, 14.39 ton /fed for fresh yield of bulb; 6.70, 6.41 for bulb diameter, 1.56, 1.46 for neck diameter, 54.90, 48.17 for plant height and 8.40, 8.0 for leaves numbers in $1^{\text {st }}$ and $2^{\text {nd }}$ seasons, respectively. And the increases of bulb TSS, carbohydrates and protein $\%$ reached to $27.67,27.54 \%$ for TSS; 15.69 , $16.73 \%$ for Carbohydrates and 55.05 \& $53.41 \%$ for protein relative to control treatment at $1^{\text {st }}$ and $2^{\text {nd }}$ seasons, respectively. Also the best treatment recorded highest values of $N, K$ as concentration and uptake of onion bulb in tow studied seasons. The available amount of $N$ and $K$ in soil after harvesting onion plants increased with increasing acids fertigation and foliar application of KS.
\end{abstract}

Key Words: Humic acid, Amino acid, Potassium Silicate, Onion plant, soil.

\section{INTRODUCTION}

Onion (Allium cepa L.) is botanically included in the Liliaceae family and species are found across a wide range in Europe, Asia, N. America and Africa. World onion production has increased by at least $25 \%$ over the past 10 years with current production being around 44 million tones making it the second most important horticultural crop after tomatoes. Because of their storage characteristics and durability for shipping, onions have always been traded more widely than most vegetables. Onions are versatile and are often used as an ingredient in many dishes and are accepted by almost all traditions and cultures. Onion consumption is increasing significantly, particularly in the USA and this is partly because of heavy promotion that links flavor and health. Onions are rich in two chemical groups that have perceived benefits to human health.

Potassium silicate (KS) is the name for a family of inorganic compounds. The most common KS has the formula $\mathrm{K}_{2} \mathrm{SiO}_{3}$, samples of which contain varying amounts of water. These are white solids or colorless solutions. Some researchers demonstrated that KS had positive effects on plant growth, yield and fruit quality of plants. Additionally, EL-Desuki, et al ., (2006) indicated that the vegetative growth of onion plants, total bulb yield as well as bulb quality and minerals uptake were increased by adding potassium fertilizer as foliar application. Ghoname, et al .,(2007) stated that $1 \%$ of $\mathrm{K}$ as a foliar spray resulted in the highest values in vegetative growth characters (plant length, leaves number, neck diameter, leaves fresh and dry weight as well as bulb fresh and dry weight) and also gave the highest total yield and quality of onion bulb (bulb weight, diameter, length and TSS. Awatef, et al., (2015) reported that the bulb measurements expressed as (bulb length, bulb diameter, average bulb weight, TSS and carbohydrates content, as well as bulb chemical composition ( $\mathrm{N}, \mathrm{P}, \mathrm{K}$ and protein) were increased with increasing potassium fertilization rates either as foliar spray or soil application.

Humic acid (HA) is one of the most important components of bioliquid complex. Because of its molecular structure, it provides numerous benefits to crop production. It assists in transferring micronutrients from the soil to the plant, enhances water retention, increases seed germination rates, improves water, air, and roots penetration, and stimulates development of micro flora population in soils. Humic acid plays an important

DOI: $10.21608 / A S E J A I Q J S A E .2020 .140926$

${ }^{1,2}$ Desert Research Center, Plant Production Dept.

${ }^{3}$ Desert Research Center, Soil Fertility and Microbiology Dept.

Received December 02, 2020, Accepted, December 31, 2020 
role in improving soil $\mathrm{pH}$ which reflected on elements availability to absorb by plant roots and consequently improve plant growth and productivity. Also it has many beneficial effects on soil structure and soil microbial populations as well as increase modify mechanisms involved plant growth stimulation, cell permeability and nutrient uptake (Vaughan and Ord, 1985). Akinremi et al. (2000) and El-Desuki (2006) reported that growth (number and fresh weight of leaves) and yield of onion were gradually and significantly increased with increasing the level of HA application from 0 to $6 \mathrm{~L} / \mathrm{fed}$. Ahamed et al., (2013) stated that foliar spraying with HA resulted in the highest growth characters, total and marketable yields, total culls and bulb weight as well as TSS $\%$, dry matter and total weight loss percentages at storage period compared with the control treatment.

Amino acids (AA) are a well-known bio-stimulant which has positive effects on plant growth, yield and significantly mitigates the injuries caused by abiotic stresses (Kowalczyk and Zielony, 2008). Tugnoli and Bettini (2003) concluded that the use of amino acids as foliar spraying contribute in overcoming the nutritional and environmental deficiencies that arise during the crop growth. In addition, reported that the foliar application of amino acids caused an enhancement in plant growth, fruit yield and its components (El-Shabasi et al. 2005) on garlic (Awad et al., 2007) on potato, and (Faten et al., 2010) on Squash.
Thus the main target of this work is to study the effect of the application humic and amino acids as fertigation and foliar application of potassium silicates on the vegetative growth, yield parameters and bulb chemical composition of onion plants grown under Siwa Oasis conditions. Also, study the available of $\mathrm{N}$ and $\mathrm{K}$ in soil at the end of the experiment.

\section{MATERIALS AND METHODS}

This study was carried out at Siwa Research Station, Desert Research Center, Khimisa Farm, Matrouh Governorate, during two successive winter seasons, i.e., $2014 / 2015$ and $2015 / 2016$ to study the effect of the fertigation of four combinations of both humic $(\mathrm{H})$ and Amino acid (A) as (control, $2 \mathrm{~L} \mathrm{H}, 2 \mathrm{~L} \mathrm{~A}$ and $2 \mathrm{~L} \mathrm{H}+2$ $\mathrm{L} \mathrm{A} /$ fed.) as well as the foliar application of three rates of potassium silicate (KS), i.e., control (tap water), 5 and $10 \mathrm{~g} \mathrm{KS} / 1$ on the growth, yield, yield components and bulb chemical composition of onion plants c.v (Red behery).

Foliar and soil fertigation treatments were applied at three times, i.e., after 30, 60 and 90 days from planting date. The experiment was irrigated by drip irrigation system. The chemical analysis of irrigation water was carried out using the standard method of Page et al., (1982) as presented in Table (1b). Some physical and chemical soil properties of the studied site were determined according to Page et al., (1982) and Klute (1986), Table (1a).

Table 1a. Some physical and chemical properties of the experiment soil

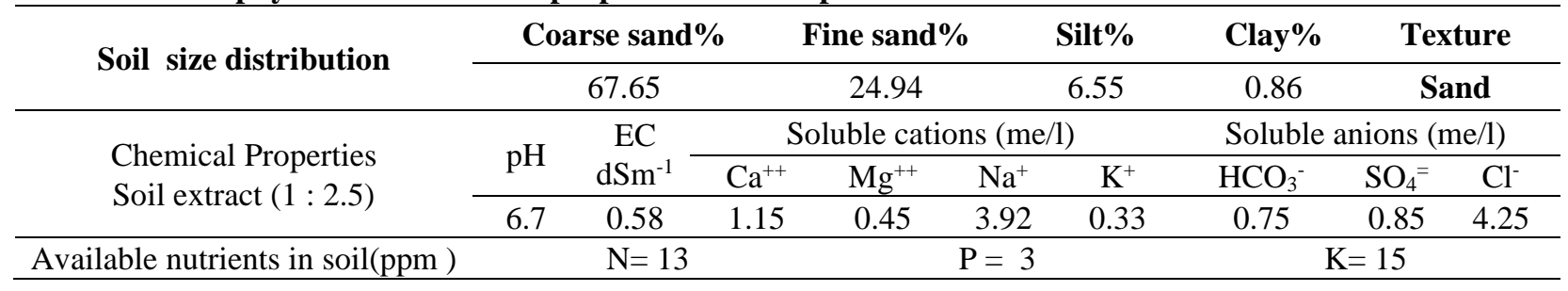

PH: Acidity, EC.: Electrical conductivity, $\quad \mathrm{dSm}^{-1}$ : decisiemens per meter, me/l: mille equivalent per liter.

Table 1b. Chemical analysis data of the applied irrigation water

\begin{tabular}{|c|c|c|c|c|c|c|c|c|c|}
\hline Parameters & $\mathrm{PH}$ & $\begin{array}{c}\text { E. C } \\
\text { dsm }^{-1}\end{array}$ & & luble C & ns $(\mathrm{m}$ & & Solu & Anions & / 1$)$ \\
\hline \multirow{2}{*}{ Values } & \multirow{2}{*}{7.1} & \multirow{2}{*}{6.38} & $\mathrm{Ca}^{++}$ & $\mathrm{Mg}++$ & $\mathrm{Na}^{+}$ & $\mathrm{K}^{+}$ & $\mathrm{HCO}_{3}^{-}$ & $\mathrm{SO} 4=$ & $\mathrm{Cl}^{-}$ \\
\hline & & & 10.1 & 13.32 & 39.4 & 1.17 & 9.35 & 15.1 & 39.54 \\
\hline
\end{tabular}

PH: Acidity, EC.: Electrical conductivity, dSm-1: decisiemens per meter, me/l: mille equivalent per liter. 
A liquid commercial product of humic acid substance used consists of humic acid $91 \%+\mathrm{P}, \mathrm{Fe}, \mathrm{Zn}(1 \%)$. And a liquid commercial product of amino acids mixture consists of $(0.56 \%$ leucine, $1.91 \%$ alanine, $1.8 \%$ valine, $0.42 \%$ arginin, $8.1 \%$ glutamic, $0.62 \%$ aspartic, $2.33 \%$ lysine, $0.41 \%$ threonine, $2.36 \%$ phenylalanine, $0.40 \%$ histidin, $2.37 \%$ tyrosine, $2.55 \%$ glycine, $0.42 \%$ isoleucine, $0.29 \%$ serine, $0.46 \%$ proline, $4 \% \mathrm{~N}, 5 \% \mathrm{~K}_{2} \mathrm{O}$ and $1 \% \quad \mathrm{P}_{2} \mathrm{O}_{5}$ were used as a source of amino acids mixture.

Organic manure was added at the rate of $20 \mathrm{~m}^{3} / \mathrm{fed}$. Which was mixed with calcium super-phosphate $(15.5 \%$ $\mathrm{P}_{2} \mathrm{O}_{5}$ ) at the rate of $150 \mathrm{~kg} / \mathrm{fed}$ during soil preparation. Nitrogen fertilizer was applied as ammonium sulphate $(20.5 \% \mathrm{~N})$ at $300 \mathrm{~kg} / \mathrm{fed}$. Where the total quantity was divided into equal five doses after 30, 50, 70, 90 and 110 days from planting. Onion seedlings were planted on the $1^{\text {st }}$ and $3^{\text {rd }}$ week of November of the $1^{\text {st }}$ and $2^{\text {nd }}$ growing seasons, respectively. Experimental area was 1/400 fed., $(10.5 \mathrm{~m} . \mathrm{L} \times 1.0 \mathrm{~m} . \mathrm{W})$, which is consisted of six ridges. The planting within six lines for each ridge $10 \mathrm{~cm}$ a part between seedlings. The experiment was conducted in a split plot design with three replicates. The main plots was the three rates of foliar spray of KS, while the fertigation treatments (control, HA, AA and combination) were allocated in the sub main plots.

\section{Recorded data:}

\section{Growth and yield parameters:}

Five plants were taken randomly from each plot after 120 days from planting for determining the following parameters, i.e., plant height $(\mathrm{cm})$, leaves No., head diameter $(\mathrm{cm})$, neck diameter $(\mathrm{cm})$, total bulb yield $(\mathrm{Mg} / \mathrm{fed}$.) and bulb dry weight yield ( $\mathrm{kg} / \mathrm{fed})$.

\section{Bulb chemical composition:}

Dry materials of plant samples (bulb) after harvesting were wet digested using mixture of $\mathrm{H}_{2} \mathrm{SO}_{4}$ and $\mathrm{HClO}_{4}(1$ : 4) as recommended by Peterburgski (1968) and the following chemical analyses were determined; total nitrogen using microkjeldahl method, potassium by flame photometer according to Black, et al. (1985) and Chapman and Pratt (1961). Some chemical of onion bulb quality parameters such as carbohydrate (\%) was determined as described by Hedge and Hofreiter (1962), crude protein (\%) was calculated by multiplying the total $\mathrm{N}$ by 6.25 and the total soluble solids percentage (TSS $\%$ ) was determined by using a JK-SR-113ATC digital Hand Refractometer.

\section{RESULTS AND DISCUSSION}

\section{Effect of both organic acids fertigation and spray with potassium silicate on:}

\section{A- Growth parameters of onion plants:}

Growth parameters such as onion plant height $(\mathrm{cm})$ and leaves number are presented in Table (2). The obtained results indicated that there are significant positive effects of both organic acids fertigation and potassium silicate (KS) spray on onion plant height and leaves number in both the studied two seasons. Humic acid application show higher values than amino acids for plant height and leaves number. It is noticed that, the interaction between using the different rate of foliar spray of potassium and (humic + amino) acids gave the highest values of plant height and leaves number which reached to $54.90,48.17$ for plant height and $8.40 \& 8.0$ for leaves numbers in $1^{\text {st }}$ and $2^{\text {nd }}$ seasons, respectively. The obtained positive effect may due to the role of humic, amino acids and potassium on the plant growth. These results agreed with those obtained by El-Desuki (2004), Awad et al. (2007), Ghoname et al. (2007), Kowalczyk \& Zielony (2008), Faten et al., (2010), Ahamed et al. (2013) and Awatef, et al. (2015).

\section{B- Yield and its components:}

Yield parameters, i. e., bulb diameters, neck diameter, fresh total yield (ton/fed.) and dry weight of bulb (ton/fed) were presented in Table (2 and 3), there are positive significant effects of both potassium foliar spray and fertigation by humic, amino acids on onion plants in the studied seasons. The highest values of yield and yield parameters were cleared with humic acid than amino acid. Moreover, the greatest values of yield parameters were found with high application rate of foliar $\mathrm{K}+$ combined with $(\mathrm{H}+\mathrm{A})$, where they reached to, 2.21, 2.10 ton /fed for dry weight of bulb; 15.33, 14.39 ton /fed for fresh yield of bulb; 6.70, 6.41 for bulb diameter and 1.56, 1.46 for neck diameter in $1^{\text {st }}$ and $2^{\text {nd }}$ seasons, respectively.

The positive effect of the interaction between humic, amino acids and potassium application may be due to balance fertilization and their important roles as a soil amendments and foliar spray of potassium, these results are agreed with those obtained by El-Desuki (2004), Awad et al. (2007), Ghoname, et al. (2007), Kowalczyk \& Zielony (2008), Faten, et al., (2010), Ahamed et al. (2013) and Awatef, et al. (2015). 
Table 2. Effect of organic acids fertigation and spray with potassium silicate on growth and yield parameters of onion plants through the studied two seasons

\begin{tabular}{|c|c|c|c|c|c|c|c|c|}
\hline $\begin{array}{l}\text { Potassium silicate } \\
\text { (KS) spray (A) }\end{array}$ & Control & $5 \mathrm{gL}^{-1}$ & $10 \mathrm{gL}^{-1}$ & Mean & control & $5 \mathrm{gL}^{-1}$ & $\operatorname{10g} L^{-1}$ & Mean \\
\hline \multirow[b]{2}{*}{ Organic acids (B) } & \multicolumn{4}{|c|}{ Plant height $(\mathrm{cm})$} & \multicolumn{4}{|c|}{ Leaves number } \\
\hline & \multicolumn{8}{|c|}{$1^{\text {st }}$ Season } \\
\hline Control & 34.23 & 41.13 & 35.45 & 36.94 & 6.20 & 6.10 & 6.07 & 6.12 \\
\hline $\mathrm{H}$ & 45.60 & 41.83 & 46.57 & 44.67 & 6.67 & 6.83 & 7.67 & 7.06 \\
\hline Amino & 43.67 & 40.83 & 42.63 & 42.38 & 6.20 & 6.50 & 7.47 & 6.72 \\
\hline $\mathrm{H}+\mathrm{A}$ & 49.47 & 51.80 & 54.90 & 52.06 & 8.13 & 8.40 & 8.37 & 8.30 \\
\hline Mean & 43.24 & 43.90 & 44.89 & & 6.80 & 6.96 & 7.39 & \\
\hline \multirow[t]{2}{*}{$\mathrm{LSD}_{0.05 \%}$} & $A=0.254$ & $\mathrm{~B}=0.36$ & $\mathrm{~A} \times \mathrm{B}=0.63$ & & $A=0.039$ & $\mathrm{~B}=0.11$ & $\mathrm{~A} \times \mathrm{B}=0.20$ & \\
\hline & \multicolumn{8}{|c|}{$2^{\text {nd }}$ Season } \\
\hline Control & 28.73 & 31.73 & 35.83 & 32.10 & 4.97 & 5.43 & 6.13 & 5.51 \\
\hline $\mathrm{H}$ & 33.13 & 34.53 & 43.27 & 36.98 & 5.63 & 6.43 & 7.13 & 6.40 \\
\hline Amino & 31.17 & 33.87 & 41.43 & 35.49 & 5.40 & 6.00 & 6.53 & 5.98 \\
\hline $\mathrm{H}+\mathrm{A}$ & 37.07 & 39.77 & 48.17 & 41.67 & 6.47 & 7.67 & 8.00 & 7.38 \\
\hline Mean & 32.53 & 34.98 & 42.18 & & 5.62 & 6.38 & 6.95 & \\
\hline \multirow[t]{3}{*}{$\mathrm{LSD}_{0.05 \%}$} & $\mathrm{~A}=0.160$ & $\mathrm{~B}=0.40$ & $\mathrm{~A} \times \mathrm{B}=0.69$ & & $\mathrm{~A}=0.031$ & $\mathrm{~B}=0.10 \quad A$ & $\mathrm{~A} \times \mathrm{B}=0.17$ & \\
\hline & \multicolumn{4}{|c|}{ Bulb diameter $(\mathrm{cm})$} & \multicolumn{4}{|c|}{ neck diameter of Bulb $(\mathrm{cm})$} \\
\hline & \multicolumn{8}{|c|}{$1^{\text {st }}$ Season } \\
\hline Control & 4.57 & 4.83 & 5.07 & 4.82 & 0.75 & 1.03 & 0.95 & 0.91 \\
\hline $\mathrm{H}$ & 5.53 & 5.25 & 5.58 & 5.46 & 0.94 & 1.20 & 1.27 & 1.14 \\
\hline Amino & 5.13 & 4.83 & 5.36 & 5.11 & 0.88 & 1.11 & 1.21 & 1.07 \\
\hline $\mathrm{H}+\mathrm{A}$ & 5.68 & 6.07 & 6.70 & 6.15 & 1.41 & 1.47 & 1.56 & 1.48 \\
\hline Mean & 5.23 & 5.25 & 5.68 & & 0.99 & 1.20 & 1.25 & \\
\hline \multirow[t]{2}{*}{$\mathrm{LSD}_{0.05 \%}$} & $\mathrm{~A}=0.02$ & $\mathrm{~B}=0.09$ & $\mathrm{~A} \times \mathrm{B}=0.16$ & & $\mathrm{~A}=0.03$ & $\mathrm{~B}=0.03$ & $\mathrm{~A} \times \mathrm{B}=0.05$ & \\
\hline & \multicolumn{8}{|c|}{$2^{\text {nd }}$ Season } \\
\hline Control & 4.10 & 4.40 & 4.73 & 4.41 & 0.64 & 0.86 & 0.90 & 0.80 \\
\hline $\mathrm{H}$ & 4.60 & 4.65 & 5.50 & 4.92 & 0.74 & 0.94 & 1.24 & 0.97 \\
\hline Amino & 4.43 & 4.45 & 5.17 & 4.68 & 0.71 & 0.90 & 1.15 & 0.92 \\
\hline $\mathrm{H}+\mathrm{A}$ & 5.63 & 5.30 & 6.41 & 5.78 & 1.40 & 1.32 & 1.46 & 1.39 \\
\hline Mean & 4.69 & 4.70 & 5.45 & & 0.87 & 1.01 & 1.19 & \\
\hline $\mathrm{LSD}_{0.05 \%}$ & $\mathrm{~A}=0.10$ & $\mathrm{~B}=0.09$ & $\mathrm{~A} \times \mathrm{B}=0.16$ & & $\mathrm{~A}=0.01$ & $\mathrm{~B}=0.01$ & $\mathrm{~A} \times \mathrm{B}=0.02$ & \\
\hline
\end{tabular}

Table 3. Effect of organic acids fertigation and spray with potassium silicate on bulb fresh and dry (ton /fed ) of onion plants through the studied two seasons

\begin{tabular}{|c|c|c|c|c|c|c|c|c|}
\hline $\begin{array}{l}\text { Potassium silicate } \\
\text { (KS) spray (A) }\end{array}$ & Control & $5 \mathrm{gL}^{-1}$ & $\operatorname{10g} L^{-1}$ & Mean & control & $5 \mathrm{gL}^{-1}$ & $\operatorname{10g} L^{-1}$ & Mean \\
\hline & \multicolumn{4}{|c|}{ Total bulb fresh yield (ton /fed) } & \multicolumn{4}{|c|}{ Total bulb dry yield (ton /fed) } \\
\hline \multicolumn{9}{|c|}{$1^{\text {st }}$ Season } \\
\hline Control & 6.56 & 6.63 & 10.93 & 8.04 & 0.82 & 0.82 & 1.38 & 1.00 \\
\hline $\mathrm{H}$ & 10.48 & 10.44 & 11.49 & 10.81 & 1.34 & 1.41 & 1.55 & 1.43 \\
\hline Amino & 8.17 & 9.33 & 10.56 & 9.35 & 1.07 & 1.18 & 1.42 & 1.22 \\
\hline $\mathrm{H}+\mathrm{A}$ & 11.59 & 14.03 & 15.33 & 13.65 & 1.52 & 1.93 & 2.21 & 1.89 \\
\hline Mean & 9.20 & 10.11 & 12.08 & & 1.19 & 1.33 & 1.64 & \\
\hline $\mathrm{LSD}_{0.05 \%}$ & $\mathrm{~A}=0.02$ & $\mathrm{~B}=0.03$ & $\mathrm{~A} \times \mathrm{B}=0.05$ & & $\mathrm{~A}=0.01$ & $\mathrm{~B}=0.01$ & $\mathrm{~A} \times \mathrm{B}=0.01$ & \\
\hline \multicolumn{9}{|c|}{$2^{\text {nd }}$ Season } \\
\hline Control & 6.47 & 6.50 & 9.75 & 7.57 & 0.81 & 0.82 & 1.24 & 0.96 \\
\hline $\mathrm{H}$ & 9.36 & 9.73 & 10.66 & 9.92 & 1.22 & 1.33 & 1.48 & 1.34 \\
\hline Amino & 8.43 & 8.61 & 9.98 & 9.01 & 1.08 & 1.30 & 1.35 & 1.24 \\
\hline $\mathrm{H}+\mathrm{A}$ & 10.18 & 12.96 & 14.39 & 12.51 & 1.37 & 1.61 & 2.10 & 1.69 \\
\hline Mean & 8.61 & 9.45 & 11.20 & & 1.12 & 1.27 & 1.54 & \\
\hline $\mathrm{LSD}_{0.05 \%}$ & $A=0.02$ & $B=0.02$ & $\mathrm{~A} \times \mathrm{B}=0.04$ & & $A=0.04$ & $\mathrm{~B}=0.07$ & $\mathrm{~A} \times \mathrm{B}=0.12$ & \\
\hline
\end{tabular}


Increasing application of KS increased significantly the yield, where the increases of fresh yield reached about $66 \% \& 50.7 \%$ with high rate of $\mathrm{KS}$ in $1^{\text {st }}$ and $2^{\text {nd }}$ season, respectively. The corresponding increase in fresh yield were recorded, $59.8 \% \& 44.9 \%$ for application $(\mathrm{H}) ; 24.5$ $\% \& 30.5 \%$ for $(\mathrm{A})$ and $76.7 \% \& 57.3 \%$ for $(\mathrm{H}+\mathrm{A})$ in $1^{\text {st }}$ and $2^{\text {nd }}$ seasons, respectively.

\section{Chemical composition of onion bulb plants:}

Data presented in Table (3) showed the effect of foliar application of potassium and fertigation by humic and amino acids individually or in combination on the concentration (\%) and uptake $(\mathrm{kg} / \mathrm{fed}$.) of $\mathrm{N}$ and $\mathrm{K}$ in onion bulb at $1^{\text {st }}$ and $2^{\text {nd }}$ seasons.

Data in Table (4) showed that sprayed of potassium silicate from 0 to $10 \mathrm{~g} / \mathrm{l}$ significantly increased the $\mathrm{N}(\%)$, $\mathrm{K}(\%)$ concentrations and uptake $(\mathrm{kg} / \mathrm{fed})$ in onion bulb in the studied two seasons. The highest values were obtained with higher level of potassium $(10 \mathrm{~g} / \mathrm{l}$ as potassium silicates). Furthermore, the highest values of $\mathrm{N}, \mathrm{K} \%$ in onion bulb were $1.89,1.91 \% \& 1.57$ and 1.58 $\%$ in the two seasons respectively. Also the highest values of $\mathrm{N}$ and $\mathrm{K}$ uptake ( $\mathrm{kg} / \mathrm{fed}$ ) reached to $41.8,40.08$ and $34.67,33.28$ in $1^{\text {st }}$ and $2^{\text {nd }}$ seasons, respectively.

However, application of humic and amino acids increased significantly both the concentrations of $\mathrm{N} \& \mathrm{~K}$ $(\%)$ and uptake $(\mathrm{kg} / \mathrm{fed})$ in onion bulb at the studied two seasons. It is noticed that fertigation by Humic acid gave the highest values of $\mathrm{N} \& \mathrm{~K}$ as concentration or uptake in onion $\mathrm{s}$ than fertigation by amino acid in the two studied seasons. Whereas, supplying onion plants by (Humic + Amino) acids gave the highest mean values $1.62,1.65$ \& $1.37,1.38$ of $\mathrm{N} \& \mathrm{~K}$ and $31.13-, 28.44(\mathrm{~kg} / \mathrm{fed})$ for $\mathrm{N}$ uptake and $26.17,23.80(\mathrm{~kg} / \mathrm{fed})$ for $\mathrm{K}$ uptake in $1^{\text {st }}$ and $2^{\text {nd }}$ seasons, respectively.

Table 4. Effect of the studied treatments on the concentration (\%) and uptake of $\mathrm{N}$ and $\mathrm{K}(\mathrm{kg} / \mathrm{fed})$ of onion bulb in the studied two seasons

\begin{tabular}{|c|c|c|c|c|c|c|c|c|}
\hline $\begin{array}{l}\text { Potassium silicate } \\
\text { (KS) spray (A) }\end{array}$ & Control & $5 \mathrm{gl}^{-1}$ & $10 \mathrm{gl}^{-1}$ & Mean & Control & $5 \mathrm{gl}^{-1}$ & $10 \mathrm{gl}^{-1}$ & Mean \\
\hline Organic acids (B) & \multicolumn{4}{|c|}{$\mathbf{N}(\%)$} & \multicolumn{4}{|c|}{$\mathbf{K}(\%)$} \\
\hline \multicolumn{9}{|c|}{$1^{\text {st }}$ season } \\
\hline Control & 1.22 & 1.32 & 1.35 & 1.30 & 0.77 & 1.14 & 1.18 & 1.03 \\
\hline $\mathrm{H}$ & 1.35 & 1.43 & 1.63 & 1.47 & 1.18 & 1.26 & 1.51 & 1.32 \\
\hline Amino & 1.31 & 1.40 & 1.51 & 1.41 & 1.10 & 1.21 & 1.34 & 1.22 \\
\hline $\mathrm{H}+\mathrm{A}$ & 1.45 & 1.52 & 1.89 & 1.62 & 1.23 & 1.30 & 1.57 & 1.37 \\
\hline Mean & 1.33 & 1.42 & 1.60 & & 1.07 & 1.23 & 1.40 & \\
\hline $\mathrm{LSD}_{0.05 \%}$ & $\mathrm{~A}=0.02$ & $\mathrm{~B}=0.02$ & $\mathrm{~A} \times \mathrm{B}=0.03$ & & $\mathrm{~A}=0.01$ & $\mathrm{~B}=0.01$ & $\mathrm{~A} \times \mathrm{B}=0.02$ & \\
\hline \multicolumn{9}{|c|}{$2^{\text {nd }}$ season } \\
\hline Control & 1.24 & 1.32 & 1.35 & 1.31 & 0.86 & 1.14 & 1.19 & 1.07 \\
\hline $\mathrm{H}$ & 1.36 & 1.45 & 1.63 & 1.48 & 1.21 & 1.28 & 1.51 & 1.33 \\
\hline Amino & 1.34 & 1.42 & 1.52 & 1.43 & 1.13 & 1.24 & 1.34 & 1.23 \\
\hline $\mathrm{H}+\mathrm{A}$ & 1.49 & 1.54 & 1.91 & 1.65 & 1.24 & 1.32 & 1.58 & 1.38 \\
\hline Mean & 1.36 & 1.43 & 1.60 & & 1.11 & 1.25 & 1.41 & \\
\hline $\mathrm{LSD}_{0.05 \%}$ & $\mathrm{~A}=0.01$ & $\mathrm{~B}=0.01$ & $\mathrm{~A} \times \mathrm{B}=0.01$ & & $\mathrm{~A}=0.01$ & $\mathrm{~B}=0.02 \quad \mathrm{~A}$ & $\mathrm{~A} \times \mathrm{B}=0.03$ & \\
\hline \multicolumn{5}{|c|}{ N uptake $(\mathrm{kg} / \mathrm{fed})$} & \multicolumn{4}{|c|}{ K uptake (kg/fed) } \\
\hline \multicolumn{9}{|c|}{$1^{\text {st }}$ season } \\
\hline Control & 9.99 & 10.81 & 18.58 & 13.13 & 6.28 & 9.28 & 16.24 & 10.60 \\
\hline $\mathrm{H}$ & 18.09 & 20.16 & 25.26 & 21.17 & 15.81 & 17.77 & 20.46 & 18.01 \\
\hline Amino & 14.01 & 16.52 & 21.44 & 17.32 & 11.77 & 14.28 & 17.32 & 14.46 \\
\hline $\mathrm{H}+\mathrm{A}$ & 22.15 & 29.43 & 41.80 & 31.13 & 18.74 & 25.11 & 34.67 & 26.17 \\
\hline Mean & 16.06 & 19.23 & 26.77 & & 13.15 & 16.61 & 22.17 & \\
\hline $\mathrm{LSD}_{0.05 \%}$ & $\mathrm{~A}=0.21$ & $\mathrm{~B}=0.28$ & $\mathrm{~A} \times \mathrm{B}=0.49$ & & $A=0.17$ & $\mathrm{~B}=0.21$ & $\mathrm{~A} \times \mathrm{B}=0$. & \\
\hline \multicolumn{9}{|c|}{$2^{\text {nd }}$ season } \\
\hline Control & 10.07 & 10.81 & 16.81 & 12.56 & 6.99 & 9.34 & 14.78 & 10.37 \\
\hline $\mathrm{H}$ & 16.50 & 19.33 & 24.10 & 19.98 & 14.68 & 17.11 & 22.28 & 18.02 \\
\hline Amino & 14.40 & 18.49 & 20.55 & 17.81 & 12.14 & 16.10 & 18.08 & 15.44 \\
\hline $\mathrm{H}+\mathrm{A}$ & 20.41 & 24.82 & 40.08 & 28.44 & 16.91 & 21.21 & 33.28 & 23.80 \\
\hline Mean & 15.35 & 18.36 & 25.39 & & 12.68 & 15.94 & 22.11 & \\
\hline $\mathrm{LSD}_{0.05 \%}$ & $A=0.63$ & $\mathrm{~B}=1.06$ & $\mathrm{~A} \times \mathrm{B}=1.84$ & & $A=0.52$ & $\mathrm{~B}=0.92$ & $\mathrm{~A} \times \mathrm{B}=1.6$ & \\
\hline
\end{tabular}




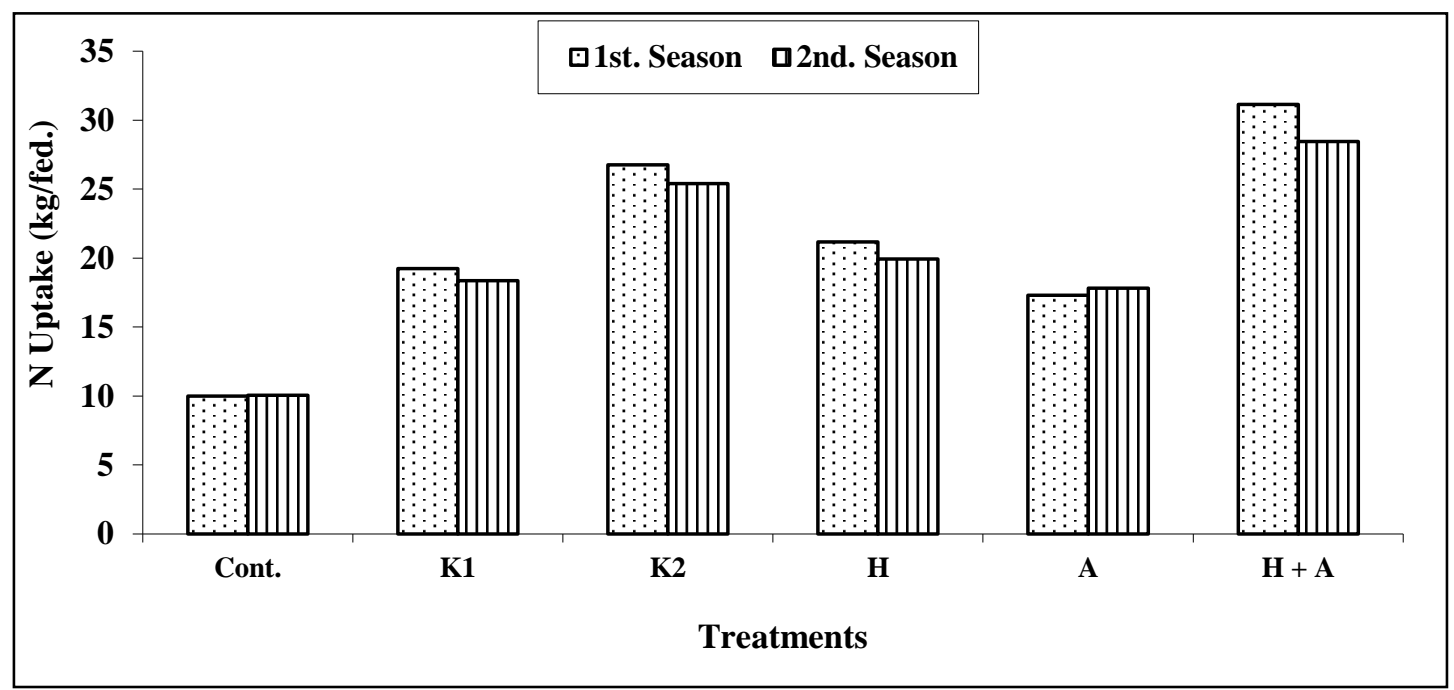

Fig. 1. Effect of the studied treatments on $\mathbf{N}$ uptake (kg /fed.) by onion bulb in the studied two seasons

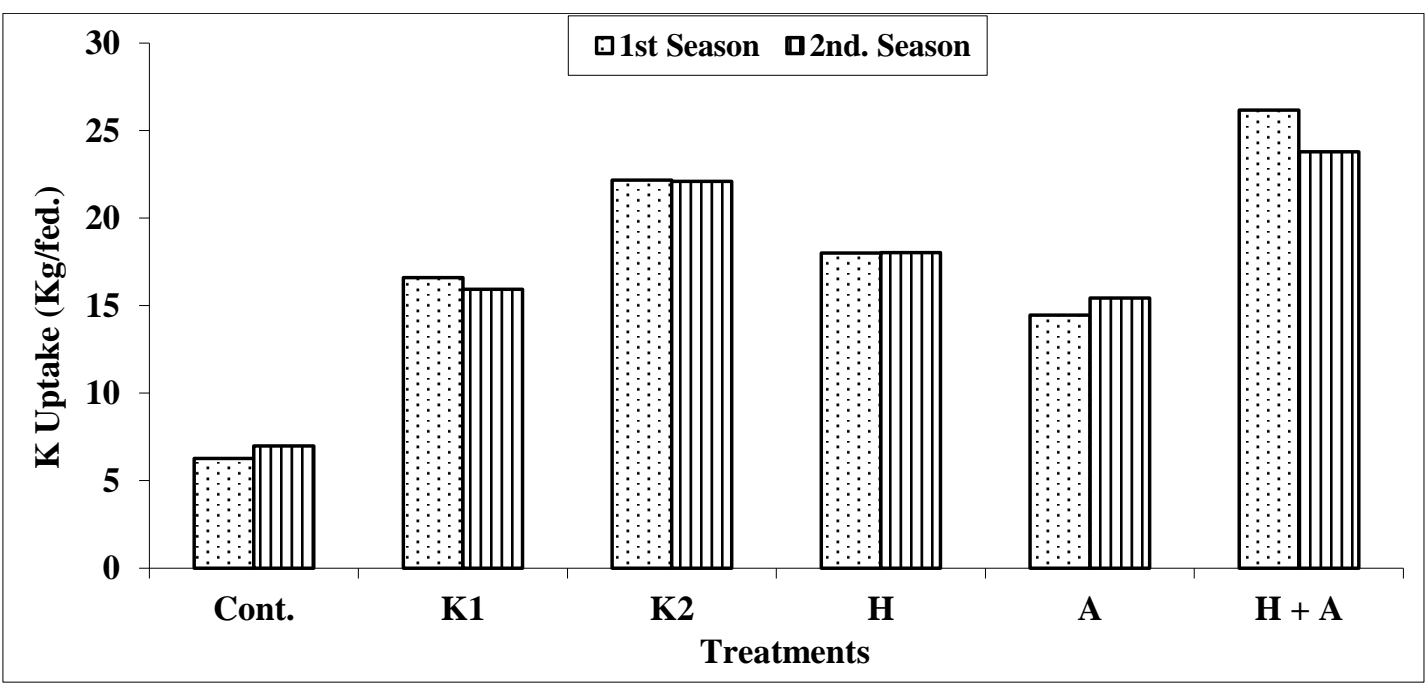

Fig. 2. Effect of the studied treatments on $\mathrm{K}$ uptake (kg/fed) by onion bulb in the two studied seasons

With respect to the triple interaction, the results indicated that, addition (high level of $\mathrm{KS}+\mathrm{H}+\mathrm{A}$ ) were the best treatment and gave the highest mean values of the elements concentration and uptake of onion bulb. The increase of nutrients concentration and uptake may be due to the effect of $\mathrm{K}$ on increasing growth of plants and acids fertigation increases available nutrients in soil to the plants. These results are agreed with Ghoname et al. (2007), Ahamed et al. (2013) and Awatef et al. (2015).

\section{D - Quality of bulb onion plants:}

Data recorded in Table (5) indicated that the percentages TSS, carbohydrates and protein in onion bulb were statistically increased by increasing potassium foliar application and fertigation by Humic and Amino acids in both seasons of study. The highest mean values were $11.48,11.49 \%$ for TSS; $16.09,16.14 \%$ for carbohydrates and $9.98,10.03 \%$ for protein with application of potassium ( $10 \mathrm{~g} / \mathrm{l}$ as potassium silicates) at $1^{\text {st }}$ and $2^{\text {nd }}$ seasons, respectively.

On comparative basis, it could be noticed that, humic acid gave the highest values of TSS, carbohydrates and protein \% than amino in both seasons of study.

The combined fertigation by (Humic + amino) acids gave highest values of TSS, carbohydrates and protein \% in onion bulb. While the superior effect was obtained by addition of humic + amino acids with potassium foliar application rate $10 \mathrm{~g} / \mathrm{l}$. Where the increases of bulb TSS, carbohydrates and protein $\%$ reached to $27.67,27.54 \%$ 
for TSS; $15.69,16.73 \%$ for Carbohydrates and $55.05 \&$ $53.41 \%$ for protein relative to control treatment at $1^{\text {st }}$ and $2^{\text {nd }}$ seasons, respectively. These results are similar to those obtained by El-Desuki (2004), Awad et al. 2007,
Ghoname, et al (2007), Kowalczyk and Zielony), Faten, et al. (2010), Ahamed, et al. (2013) and Awatef et al (2015).

Table 5. Effect of the studied treatments on the quality of onion bulb in the studied two seasons

\begin{tabular}{|c|c|c|c|c|c|c|c|c|}
\hline \multirow[b]{2}{*}{$\begin{array}{l}\text { Potassium silicate } \\
\text { (KS) spray (A) }\end{array}$} & \multicolumn{4}{|c|}{$1^{\text {st }}$ season } & \multicolumn{4}{|c|}{$2^{\text {nd }}$ season } \\
\hline & Control & $5 \mathrm{gl}^{-1}$ & $10 \mathrm{gl}^{-1}$ & Mean & control & $5 \mathrm{gl}^{-1}$ & $10 \mathrm{gl}^{-1}$ & Mean \\
\hline Organic acids (B) & \multicolumn{8}{|c|}{ TSS (\%) } \\
\hline Control & 9.72 & 10.06 & 10.37 & 10.05 & 9.73 & 10.09 & 10.39 & 10.07 \\
\hline $\mathrm{H}$ & 11.11 & 11.75 & 11.84 & 11.57 & 11.12 & 11.70 & 11.85 & 11.56 \\
\hline Amino & 10.17 & 11.03 & 11.30 & 10.83 & 10.19 & 11.04 & 11.30 & 10.84 \\
\hline $\mathrm{H}+\mathrm{A}$ & 12.06 & 12.15 & 12.41 & 12.21 & 12.09 & 12.17 & 12.41 & 12.22 \\
\hline Mean & 10.77 & 11.25 & 11.48 & & 10.78 & 11.25 & 11.49 & \\
\hline \multirow[t]{2}{*}{$\mathrm{LSD}_{0.05 \%}$} & $\mathrm{KS}=0.035$ & $\mathrm{~B}=0.047$ & $\mathrm{KS} \times \mathrm{B}=0.082$ & & $\mathrm{KS}=0.055$ & $\mathrm{~B}=0.048$ & $\mathrm{KS} \times \mathrm{B}=0.08$ & \\
\hline & \multicolumn{8}{|c|}{ Carbohydrate (\%) } \\
\hline$\overline{\text { Control }}$ & 15.04 & 15.19 & 15.25 & 15.16 & 15.06 & 15.20 & 15.25 & 15.17 \\
\hline $\mathrm{H}$ & 15.12 & 15.25 & 15.65 & 15.34 & 15.18 & 15.32 & 16.10 & 15.53 \\
\hline Amino & 15.17 & 15.32 & 16.08 & 15.52 & 15.13 & 15.27 & 15.64 & 15.35 \\
\hline $\mathrm{H}+\mathrm{A}$ & 15.23 & 15.56 & 17.40 & 16.07 & 15.25 & 15.57 & 17.58 & 16.14 \\
\hline Mean & 15.14 & 15.33 & 16.09 & & 15.16 & 15.34 & 16.14 & \\
\hline \multirow[t]{2}{*}{$\mathrm{LSD}_{0.05 \%}$} & $\mathrm{~A}=0.08$ & $\mathrm{~B}=0.10 \quad \mathrm{~A}$ & $\mathrm{~A} \times \mathrm{B}=0.17$ & & $\mathrm{~A}=0.04$ & $\mathrm{~B}=0.07$ & $\mathrm{~A} \times \mathrm{B}=0.11$ & \\
\hline & \multicolumn{8}{|c|}{ Protein $(\%)$} \\
\hline Control & 7.63 & 8.27 & 8.44 & 8.11 & 7.77 & 8.27 & 8.46 & 8.17 \\
\hline $\mathrm{H}$ & 8.44 & 8.94 & 10.21 & 9.19 & 8.48 & 9.06 & 10.21 & 9.25 \\
\hline Amino & 8.21 & 8.73 & 9.44 & 8.79 & 8.35 & 8.88 & 9.52 & 8.92 \\
\hline $\mathrm{H}+\mathrm{A}$ & 9.08 & 9.52 & 11.83 & 10.15 & 9.33 & 9.63 & 11.92 & 10.29 \\
\hline Mean & 8.34 & 8.86 & 9.98 & & 8.48 & 8.96 & 10.03 & \\
\hline $\mathrm{LSD}_{0.05 \%}$ & $\mathrm{~A}=0.10$ & $\mathrm{~B}=0.10$ & $\mathrm{~A} \times \mathrm{B}=0$. & .17 & $\mathrm{~A}=0.04$ & $\mathrm{~B}=0.05$ & $\mathrm{~A} \times \mathrm{B}=0.08$ & \\
\hline
\end{tabular}

Table 6. Effect of the studied treatments on the available amounts of $N$ and $K(\mathrm{ppm})$ in soil after harvesting

\begin{tabular}{|c|c|c|c|c|c|c|c|c|}
\hline & \multicolumn{4}{|c|}{$1^{\text {st }}$ season } & \multicolumn{4}{|c|}{$2^{\text {nd }}$ season } \\
\hline $\begin{array}{l}\text { Potassium silicate } \\
\text { (KS) spray (A) }\end{array}$ & control & $5 \mathrm{gL}^{-1}$ & $\operatorname{10gL^{-1}}$ & Mean & Control & $5 \mathrm{gL}^{-1}$ & $\operatorname{10gL^{-1}}$ & Mean \\
\hline Organic acids (B) & \multicolumn{8}{|c|}{ Available N ( ppm) } \\
\hline Control & 14.63 & 14.70 & 14.83 & 14.72 & 12.77 & 12.78 & 12.86 & 12.80 \\
\hline $\mathrm{H}$ & 16.44 & 16.94 & 17.21 & 16.86 & 14.48 & 14.97 & 14.01 & 14.48 \\
\hline Amino & 15.21 & 15.73 & 15.76 & 15.57 & 13.35 & 13.88 & 13.90 & 13.72 \\
\hline $\mathrm{H}+\mathrm{A}$ & 17.08 & 17.52 & 17.83 & 17.48 & 15.33 & 15.63 & 15.92 & 15.62 \\
\hline Mean & 15.84 & 16.22 & 16.41 & & 13.98 & 14.31 & 14.18 & \\
\hline \multirow[t]{2}{*}{$\mathrm{LSD}_{0.05 \%}$} & $\mathrm{KS}=0.0098$ & $3 \mathrm{OA}=0$ & $118 \mathrm{KS} \times \mathrm{C}$ & $=0.0204$ & $\mathrm{KS}=0.0087$ & $\mathrm{OA}=0$ & $117 \quad \mathrm{~K}$ & $\mathrm{DA}=0.0202$ \\
\hline & \multicolumn{8}{|c|}{ Available K ( ppm ) } \\
\hline Control & 20.27 & 20.44 & 20.75 & 20.49 & 17.77 & 17.79 & 17.82 & 17.79 \\
\hline $\mathrm{H}$ & 21.46 & 21.64 & 21.94 & 21.68 & 18.48 & 18.71 & 18.86 & 18.68 \\
\hline Amino & 20.94 & 21.03 & 21.08 & 21.02 & 18.06 & 18.09 & 18.32 & 18.16 \\
\hline $\mathrm{H}+\mathrm{A}$ & 22.26 & 22.42 & 22.61 & 22.49 & 19.36 & 19.65 & 19.70 & 19.57 \\
\hline Mean & 21.23 & 21.88 & 21.60 & & 18.14 & 18.56 & 18.68 & \\
\hline $\mathrm{LSD}_{0.05 \%}$ & $\mathrm{~A}=0.0087$ & $7 \quad \mathrm{~B}=0$ & $090 \quad \mathrm{~A} \times \mathrm{B}$ & 0.0157 & $\mathrm{~A}=0.0065$ & $5 \quad \mathrm{~B}=$ & $083 \quad \mathrm{~A}$ & $=0.0143$ \\
\hline
\end{tabular}




\section{E- Effect of treatments on the available amounts of $\mathbf{N}$ and $K$ in soil after harvesting:}

Data in Table (6) showed that the studied available elements showed variable values. Adding of humic acid fertigation increased the available amounts of $\mathrm{N}$ and $\mathrm{K}$ (ppm) in soil after harvesting throughout the studied two seasons. The percentage increases of $\mathrm{N}$ reached to 14.54 and $13.13 \%$ in $1^{\text {st }}$ and $2^{\text {nd }}$ seasons respectively. While the corresponding increase of the available amount of $\mathrm{K}$ in soil reached 5.8 and $5.0 \%$.

The positive effect of humic acid may be due to its important role as a soil conditioner to increase water holding capacity and soil warmth induce soil microorganism's activity. It is noticed that fertigation by Humic acid gave highest values of available amounts of $\mathrm{N}$ and $\mathrm{K}(\mathrm{ppm})$ if compared with fertigation by Amino acid. Whereas, the combined fertigation humic and amino acids gave high values comparing to individual addition. With respect to KS effect, the highest mean values of the available $\mathrm{N}$ and $\mathrm{K}$ in soil after harvesting were associated with spraying $\mathrm{K}$ at $(10 \mathrm{~g} / \mathrm{l})$. The greatest values of available amounts of $\mathrm{N}$ and $\mathrm{K}(\mathrm{ppm})$ in soil after harvesting throughout the studied two seasons was associated with the interaction between humic, amino acids and potassium application where the values reached to $17.83 ; 15.92(\mathrm{ppm})$ for $\mathrm{N}$ and $22.61 ; 19.70(\mathrm{ppm})$ for $\mathrm{K}$ in $1^{\text {st }}$ and $2^{\text {nd }}$ seasons, respectively. The increases of nutrients concentration in soil may be acids fertigation increase the availability of nutrients in soil. These results are in accordance with those obtained by Vaughan and Ord (1985) and Kowalczyk and Zielony (2008).

\section{CONCLUSION}

Foliar spray at rate of $10 \mathrm{~g} \mathrm{KS} / \mathrm{l}$ with $(\mathrm{H})$ and $(\mathrm{A})$ either individually or combination was very effective in improving growth, yield, yield component and quality parameters than applied the spray with of $5 \mathrm{~g} \mathrm{KS} / \mathrm{l}$ during the studied two seasons compared to control treatment.

And the best treatment was observed with the integration treatment of $(\mathrm{H}+\mathrm{A}+10 \mathrm{~g} \mathrm{KS} / \mathrm{l})$ which gave the highest mean values of growth, yield, yield component and quality parameters (TSS \%, Protein $\%$ and carbohydrates \%) during the studied two seasons compared with control treatment. Also the best treatment recorded highest values of $\mathrm{N}, \mathrm{K}$ as concentration and uptake of Onion bulb in tow studied seasons. The available amount of $\mathrm{N}$ and $\mathrm{K}$ in soil after harvesting Onion plants increased with increasing acids fertigation and foliar application of KS.

\section{REFERENCES}

Ahamed, A. K., E. A. Sharief and F. H. Fathalla. 2013. Onion yield as affected by foliar application with amino and humic acids under nitrogen fertilizer levels. E. Sci. J. Crop Prod. (02): 62-72.

Akinremi, O. O., H. H. Janzen, R. L. Lemke and F. J. Larney. 2000. Response of canola, wheat and green beans to leonardite additions. Canadian J. of Soil Sci. 80: 437-443.

Awad, El-M. M., A. M. Abd El-Hameed and Z. A. El-Aimin. 2007. Effect of glycine, Lysine and nitrogen fertilizer rates on growth, yield and chemical composition of potato. J. Agric. Sci. Mansoura Univ. 32 (10): 8541-8551.

Awatef, G. B., R. M. Asmaa, M. R. Shafeek, H. A. Aisha and M. H.Magda. 2015. Growth, Yield and Bulb Quality of Onion Plants (Allium cepa L.) as Affected by Foliar and Soil Application of Potassium. Middle East J. Agric. Res. 1(4): 60-66.

Black, C. A., D. O. Evans, L. E. Ensminger, J. L. White, F. E. Clark and R.C. Dinauer. 1985. In "Methods of soil Analysis" part2: "Chemical and Microbiological properties ". $2^{\text {nd }}$ edition, p. 831-866. Soil Sci. soc. of Am. Inc pub., Madison, Wisconsin, USA.

Chapman, H. D. and F. P. Pratt. 1961. Methods of Analysis for soils, plants and waters". Dept. of soil. PI. Nutrition, Univ. of California, Davis, U.S.A. 670-681.

El Desuki, M. 2004. Response of onion plants to humic acid and mineral fertilizers application. Annal. Agric. Sci. Moshtohor. 42(2): 1955- 1964.

EL-Desuki, M.M., M. Abdel-Mouty and A. H. Ali. 2006. Response of Onion Plants to Additional Dose of Potassium Application. J. Appl. Sci. Res. 2 (9): 592-597.

El-Shabasi, M. S., Mohamed S. M., and Mahfouz S. A. (2005). Effect of foliar spray with some amino acids on growth, yield and chemical composition of garlic plants. The $6^{\text {th }}$ Arabian Conf. for Hort., Ismailia, Egypt.

Faten, S. A., A. M. Shaheen, A. A. Ahmed and R. M. Asmaa. 2010. The effect of foliar application of urea and amino acids mixtures as antioxidants on the growth and yield and characteristics of squash. Res. J. Agric. Biol. Sci, 6 (5): 583588.

Ghoname, A., A. M. El-Bassiony, G. S. Riad and M. M. Abd El-Baky. 2007. Reducing Onion Bulbs Flaking and Increasing Bulb Yield and Quality by Potassium and Calcium Application. Aust. J. of Basic and Appli. Sci. 1(4): 610-618.

Hedge, I. E. and B.T. Hofreiter. 1962. "Carbohydrate Chemistry (Eds Whistler, R. L. and Be Miller, J. N.) Academic Press New York.USA.

Klute, A. A. 1986." Method of Soil Analysis ". Part 1, $2^{\text {nd }}$ ed., Am. Soc. of Argon. Inc. publisher Madison. Wisconsin. USA.

Kowalczyk, K. and T. Zielony. 2008. Effect of Amino plant and Asahi on yield and quality of lettuce grown on Rockwool. Conf. of bio stimulators in modern agriculture, 7-8 February, Warsaw Poland. 
Page, A. L., R. H. Miller and D. R. Keeney. 1982. Methods of Soil Analysis. II: Chemical and Microbiological Properties, $2^{\text {nd }}$ ed. Am. Soc. Agron. Inc. Soil. Soil Sci. Soc. Am. Inc, Madison, Wisconsin U.S.A.

Peterburgski, A.V. 1968." Hand Book of Agronomic chemistry". Kolos publishing House, Moscow. (In Russian). PP. 29-86.
Tugnoli, V. and G. Bettini. 2003. The use of foliar fertilizer application in sugar beet growing. $1^{\text {st }}$ Joint IIRBASSBT Congress, $26^{\text {th }}$ Feb - ${ }^{\text {st }}$ March, San Antonio (USA). pp: 655660.

Vaughan, D. and B. G. Ord. 1985. An effect of soil organic matter on invertase activity in soil. Soil Bio. Bioch. 12: 449450 .

\section{الملخص العزبي}

\section{تحسين إنتاجية البصل النامى بواحة سيوة تحت تأثير الرش بسيليكات البوتاسيوم والتسميد رياً بحمى الهيوميك والامينو}

محمد رائف حافظ، جبريل عبد الله محمد، فتحى عبد الفتاح العزيزى

منفردة أومجتمعة كانت أكثر تأثيرا فى تحسين النمو

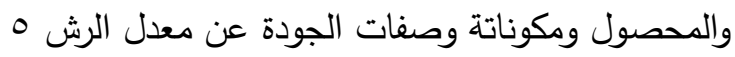

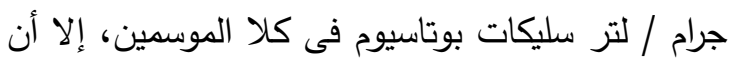

كلا المعدلين ه و • 1 جرام من سليكات البوتسيوم كان

أحسن مع حمض الهيوميك عن الاحماض الامينية فى

كل الصفات تحت الدراسة فى كلا الموسمين.

كانت أفضل معاملة هى التكامل بين حامض الهيوميك،

والأحماض الأمينية والرش بسليكات البوتاسيوم والمتمثلة فى المعاملة (r لتر حامض هيوميك + r لتر أحماض أمينية/فدان + · ( جم سليكات بوتاسيوم/لتر ) حيث أعطت أعلى قيم فى النمو والمحصول ومكوناتة وصفات الجودة للبصيلات على الاطلاق بالمقارنة بمعاملة الكنترول، كما أعطت أعلى قيم للتركيز والممتص من النتروجين

$$
\text { والبوتاسيوم فى البصيلات فى كلا الموسمين. }
$$

أدى اضافة حمض الهيوميك والاحماض الامينية مع مياة

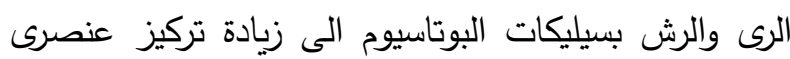
النتروجين والبوتاسيوم الميسرين بالتربة بعد حصاد المحصول.
أقيمت تجربة حقلية فى مزرعة خميسة التابعة لمحطة

بحوث سيوة - مركز بحوث الصحراء ، بواحة سيوة ، محافظة

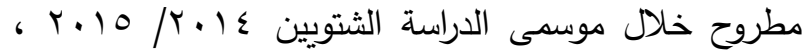

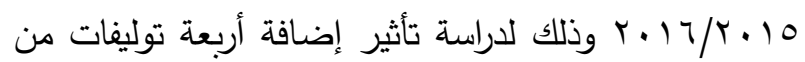

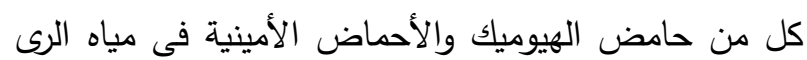
بالمعدلات (كنترول ، r لتر حامض الهيوميك ، ب لتر أحماض

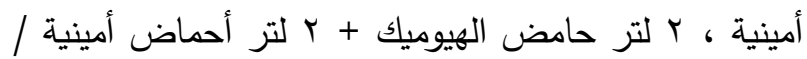
فدان) ، وأيضاً الرش الورقى بثلاث معدلات من سيليكات البوتاسيوم هى صغر ، 0 ، ، 1 جم/لتر ، على النمو والإنتاجية والجودة والمحتوى والممتص من النيتروجين والبوتاسيوم وأيضاً دراسة مستوى النيتروجين والبوتاسيوم الميسرين بالتربة بعد

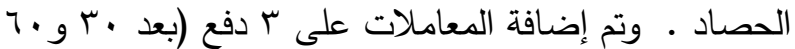
و •9 يوم من تاريخ الزراعة) واجريت التجربة بتصميم القطع المنشقة لمرة واحدة بحيث كان الرش الورقى بسيليكات البوتاسيوم هى العامل الرئيسى بينما توليفات كل من حامض الهيوميك والأحماض الأمينية هى العامل تحت الرئيسى. • أكدت النتائج أن الرش الورقى بسيليكات البوتاسيوم بمعدل • اجم/لتر مع حمض الهيوميك والاحماض الامينبة سواء 